\title{
Increased Constriction of the Ductus Arteriosus with Combined Administration of Indomethacin and Betamethasone in Fetal Rats
}

\author{
KAZUO MOMMA AND ATSUYOSHI TAKAO \\ Department of Pediatric Cardiology, The Heart Institute of Japan, Tokyo Women's Medical College, \\ Tokyo, Japan
}

\begin{abstract}
To find a better treatment for patent ductus arteriosus of preterm infants, we studied the combined effect of indomethacin and betamethasone on the fetal ductus in rats. We used a rapid whole-body freezing technique, and the ratio of the inner diameter of the ductus to the main pulmonary artery, which was 1.0 in controls, was used as an index of constriction. Indices of ductal constriction $4 \mathrm{~h}$ after administration of indomethacin $(1 \mathrm{mg} / \mathrm{kg})$ alone, betamethasone $(1 \mathrm{mg} / \mathrm{kg})$ alone or in combination in near-term rats were $0.56 \pm 0.05$ (mean \pm SEM), $0.76 \pm$ 0.06 , and $0.17 \pm 0.03$, respectively. In preterm rats too, a marked increase in fetal ductus constriction was observed with the combined administration of these two drugs. Study of the dose effect of betamethasone revealed that maximal effects were obtained with $1 \mathrm{mg} / \mathrm{kg}$ of betamethasone combined with indomethacin in both preterm and near-term fetal rats. Increased constriction of the fetal ductus with combination treatment persisted from 1 to $8 \mathrm{~h}$ after administration. Administration of betamethasone $24 \mathrm{~h}$ before the rat was killed did not augment constriction of the fetal ductus by indomethacin administered $4 \mathrm{~h}$ before they were killed. Fetal ductus constriction by sulindac, another nonsteroidal antiinflammatory drug with little inhibitory effect on renal function, also was augmented by combined use with betamethasone $(1 \mathrm{mg} / \mathrm{kg})$. In conclusion, ductal constriction was markedly increased by combined administration of indomethacin and betamethasone in near-term and preterm fetal rats. (Pediatr Res 25:69-75, 1989)
\end{abstract}

\section{Abbreviations}

DA, ductus arteriosus

PA, pulmonary artery

Since the first reports $(1,2)$ on pharmacologic closure of the patent DA of preterm infants in 1976, indomethacin has been widely used to constrict the DA of the preterm infant. However, success rates of DA closure by indomethacin treatment in preterm infants were variable, indicating that therapy with indomethacin is less than perfect $(3,4)$. Our earlier study showed fetal ductal constriction by glucocorticoid hormones, including betamethasone (5). A subsequent study revealed that combined

Received May 23, 1988; accepted September 13, 1988.

Correspondence and reprint requests Kazuo Momma, The Heart Institute of Japan, Tokyo Women's Medical College, Kawadacho 8-1, Shinjukuku, Tokyo 162, Japan.

Supported by grants from the Ministry of Education, Science, and Culture of Japan, the Welfare Ministry of Japan, the Japan Promotion Society for Cardiovascular Diseases and Japan Cardiovascular Research Foundation. administration of betamethasone and indomethacin markedly augments constriction of the fetal DA in both preterm and nearterm rats.

\section{MATERIALS AND METHODS}

Virgin Wistar rats (pregnancy period, 21.5 days) were mated overnight from 1700 to $900 \mathrm{~h}$, and the presence of sperm on vaginal smears dated the 0 day of pregnancy. These rats were fed commercial solid food and water. Indomethacin (Sumitomo Chemical Co., Osaka, Japan) or sulindac (Merck-Banyu, Tokyo, Japan) was administered through an orogastric tube in a suspension with $2 \mathrm{ml}$ water containing $5 \%$ arabic gum. Betamethasone disodium phosphate (Shionogi Pharmaceutical Co., Tokyo, Japan) was injected into the dorsum of the thorax of the pregnant rat. Fetal rats were evaluated as to activity, skin color, and turgor immediately after delivery and before freezing.

Fetal ductus arteriosus was studied using the rapid whole-body freezing technique, as reported previously $(5-8)$. Briefly, the rat was killed by cervical dislocation, fetuses were delivered quickly by cesarean section and frozen quickly by immersion in acetone cooled to $-80^{\circ} \mathrm{C}$ by dry ice. The frozen thorax was trimmed and sectioned in a frontal plane on a freezing microtome, and the inner diameters of the main PA and DA were measured under a stereoscopic microscope and a micrometer, as reported previously (5-8). The ratio of the inner diameter of the DA at its narrowest point to the PA (DA/PA) was used to evaluate the constrictive effects of the drugs.

The following five studies were conducted as shown in Table 1. Studies $1,2,3$, and 4 were done in both near-term (21st day) and preterm (19th day) rats. Two to six pregnant rats were studied for each dosage or timing as shown in Table 1. The combined effects of betamethasone and indomethacin or sulindac were studied after simultaneous administration of two drugs in studies $1,2,4$, and 5 . In study 4 , two drugs were administered separately.

In study 1 , the dose effect of betamethasone was studied $4 \mathrm{~h}$ after administration alone or in combination with indomethacin $(1 \mathrm{mg} / \mathrm{kg})$. The dose of indomethacin was $1 \mathrm{mg} / \mathrm{kg}$ in all studies, and with this dose, concentration in the fetal plasma was about $700 \mathrm{ng} / \mathrm{ml} 4 \mathrm{~h}$ after administration. This is approximately the same plasma concentration as in premature babies treated with indomethacin (9).

In study 2 the duration of DA constriction was studied at 1 , 4,8 , and $24 \mathrm{~h}$ after simultaneous administration of betamethasone $(1 \mathrm{mg} / \mathrm{kg})$ and $I$. The dose of betamethasone was set to a 1 $\mathrm{mg} / \mathrm{kg}$ in studies $2,3,4$, and 5 because study 1 showed that the augmenting effect of betamethasone administered simultaneously with indomethacin was maximal at this dose. In the 24-h study, drugs were administered at $900 \mathrm{~h}$ either on the 19 th or 21 st day, and the DA was studied on 20 th or 22 nd day. 
Table 1. Experimental protocol: four studies on ductal constriction in near-term (21st day) and preterm (19th day) fetal rats and another study on plasma indomethacin concentrations in near-term rats

\begin{tabular}{|c|c|c|}
\hline Study & $\begin{array}{c}\text { Near-term rats, } \\
\text { 21st day }\end{array}$ & $\begin{array}{l}\text { Preterm rats, 19th } \\
\text { day }\end{array}$ \\
\hline $\begin{array}{l}\text { 1: Dose effect of betamethasone } 4 \mathrm{~h} \text { after adminis- } \\
\text { tration alone or simultaneously with indometha- } \\
\text { cin }(1 \mathrm{mg} / \mathrm{kg})\end{array}$ & $\begin{array}{l}\text { No drug }=4 \\
\mathrm{I}(1)=6 \\
\mathrm{~B}(0.01)=2 \\
\mathrm{~B}(0.1)=2 \\
\mathrm{~B}(1)=2 \\
\mathrm{~B}(10)=2 \\
\mathrm{~B}(100)=2 \\
\mathrm{~B}(0.01)+\mathrm{I}(1)=3 \\
\mathrm{~B}(0.1)+\mathrm{I}(1)=2 \\
\mathrm{~B}(1)+\mathrm{I}(1)=2 \\
\mathrm{~B}(10)+\mathrm{I}(1)=3 \\
\mathrm{~B}(100)+\mathrm{I}(1)=2\end{array}$ & $\begin{array}{l}\text { No drug = } 3 \\
\mathrm{I}(1)=4 \\
\mathrm{~B}(0.01)=4 \\
\mathrm{~B}(0.1)=3 \\
\mathrm{~B}(1)=3 \\
\mathrm{~B}(10)=4 \\
\mathrm{~B}(100)=2 \\
\mathrm{~B}(0.01)+\mathrm{I}(1)=4 \\
\mathrm{~B}(0.1)+\mathrm{I}(1)=3 \\
\mathrm{~B}(1)+\mathrm{I}(1)=4 \\
\mathrm{~B}(10)+\mathrm{I}(1)=2 \\
\mathrm{~B}(100)+\mathrm{I}(1)=2\end{array}$ \\
\hline $\begin{array}{l}\text { 2: Duration of effect: simultaneously administered } \\
\text { indomethacin }(1 \mathrm{mg} / \mathrm{kg}) \text { and betamethasone }(1 \\
\mathrm{mg} / \mathrm{kg}) \text { or in separate administration }\end{array}$ & $\begin{array}{c}\mathrm{B}(1)+\mathrm{I}(1) \\
1 \mathrm{~h}=2 \\
4 \mathrm{~h}=2 \\
8 \mathrm{~h}=2 \\
24 \mathrm{~h}=2 \\
\text { B (1) only } \\
1 \mathrm{~h}=2 \\
4 \mathrm{~h}=2 \\
8 \mathrm{~h}=2 \\
24 \mathrm{~h}=4 \\
\mathrm{I}(1) \text { only } \\
1 \mathrm{~h}=2 \\
4 \mathrm{~h}=6 \\
8 \mathrm{~h}=2 \\
24 \mathrm{~h}=2\end{array}$ & $\begin{array}{c}\text { B (1) }+\mathrm{I}(1) \\
1 \mathrm{~h}=2 \\
4 \mathrm{~h}=4 \\
8 \mathrm{~h}=2 \\
24 \mathrm{~h}=2 \\
\text { B (1) only } \\
1 \mathrm{~h}=2 \\
4 \mathrm{~h}=4 \\
8 \mathrm{~h}=2 \\
24 \mathrm{~h}=2 \\
\text { I (1) only } \\
1 \mathrm{~h}=2 \\
4 \mathrm{~h}=4 \\
8 \mathrm{~h}=2 \\
24 \mathrm{~h}=2\end{array}$ \\
\hline $\begin{array}{l}\text { 3: Duration of effect of betamethasone }(1 \mathrm{mg} / \mathrm{kg}) \\
\text { alone or in combination with separately admin- } \\
\text { istered indomethacin } 4 \mathrm{~h} \text { before the study }\end{array}$ & $\begin{array}{c}\text { I (1) } 4 \mathrm{~h}+\mathrm{B}(1) \\
1 \mathrm{~h}=2 \\
4 \mathrm{~h}=2 \\
8 \mathrm{~h}=3 \\
24 \mathrm{~h}=4 \\
\text { B (1) only } \\
1 \mathrm{~h}=2 \\
4 \mathrm{~h}=2 \\
8 \mathrm{~h}=2 \\
24 \mathrm{~h}=4\end{array}$ & $\begin{array}{c}\mathrm{I}(1) 4 \mathrm{~h}+\mathrm{B}(1) \\
1 \mathrm{~h}=2 \\
4 \mathrm{~h}=4 \\
8 \mathrm{~h}=2 \\
24 \mathrm{~h}=2 \\
\text { B (1) only } \\
1 \mathrm{~h}=2 \\
4 \mathrm{~h}=4 \\
8 \mathrm{~h}=2 \\
24 \mathrm{~h}=2\end{array}$ \\
\hline $\begin{array}{l}\text { 4: Dose effect of sulindac, } 4 \mathrm{~h} \text { after administration } \\
\text { alone or with betamethasone }(1 \mathrm{mg} / \mathrm{kg})\end{array}$ & $\begin{array}{l}S(X)+B(1) \\
S(0.1)=2 \\
S(1)=2 \\
S(10)=2 \\
S(100)=2 \\
S(X) \text { only } \\
S(0.1)=2 \\
S(1)=4 \\
S(10)=2 \\
S(100)=3\end{array}$ & $\begin{array}{l}S(X)+B(1) \\
S(0.1)=2 \\
S(1)=2 \\
S(10)=2 \\
S(100)=2 \\
S(X) \text { only } \\
S(0.1)=2 \\
S(1)=2 \\
S(10)=2 \\
S(100)=2\end{array}$ \\
\hline 5: Plasma indomethacin concentration & $\begin{array}{c}\mathrm{I}(1)+\mathrm{B}(1) \\
1 \mathrm{~h}=4 \\
4 \mathrm{~h}=4 \\
8 \mathrm{~h}=4 \\
\mathrm{I}(1) \text { only } \\
1 \mathrm{~h}=4 \\
4 \mathrm{~h}=4 \\
8 \mathrm{~h}=4\end{array}$ & \\
\hline
\end{tabular}

* Doses of indomethacin (I), betamethasone (B), or sulindac (S) are indicated in $\mathrm{mg} / \mathrm{kg}$ in parentheses. Numbers of pregnant rats studied with each dosage or timing are listed after equals sign.

In study 3 , the duration of the augmenting effect of separately administered betamethasone was studied. Betamethasone (1 mg/ $\mathrm{kg}$ ) was injected $1,4,8$, or $24 \mathrm{~h}$ before the rats were killed. In the 24-h study, betamethasone was administered on the 18th day in preterm rats, or on the 20 th day in near-term rats. Indomethacin was administered $4 \mathrm{~h}$ before rats were killed in both nearterm and preterm rats.

In study 4 , the augmented constrictive effects of sulindac with 
combined administration of betamethasone were studied. Sulindac was studied because of its lack of effect on renal function $(10,11)$. According to the results of study $1,1 \mathrm{mg} / \mathrm{kg}$ betamethasone was used to augment the constrictive effects of sulindac. Betamethasone was administered simultaneously with $0.1,1,10$, or $100 \mathrm{mg} / \mathrm{kg}$ of sulindac, and the combined effects were studied $4 \mathrm{~h}$ later.

In study 5, plasma indomethacin concentrations were studied to determine the possible effect of simultaneously administered betamethasone on plasma indomethacin concentrations. Indomethacin $(1 \mathrm{mg} / \mathrm{kg})$ alone, or in combination with betamethasone $(1 \mathrm{mg} / \mathrm{kg})$ was administered to 21 -day rats. One, 4 , or $8 \mathrm{~h}$

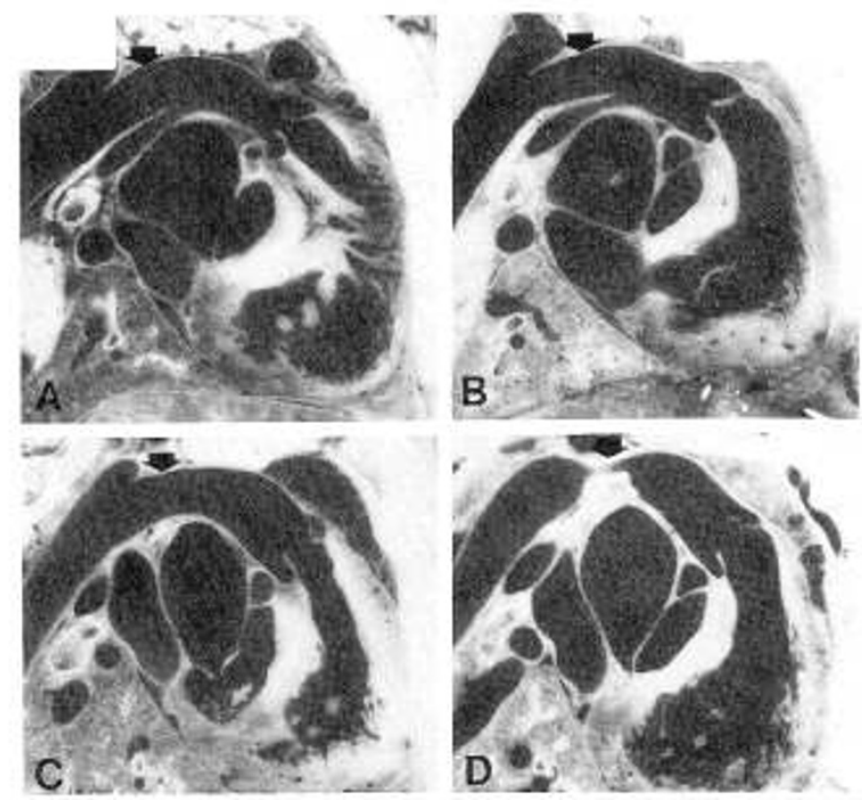

Fig. 1. Sagittal cross-sections through the right ventricle, the main pulmonary artery, the DA and the descending aorta. The DA was widely patent in control near-term rat fetus without mediation $(A)$. The DA showed only mild constriction $4 \mathrm{~h}$ after administration of either indomethacin $1 \mathrm{mg} / \mathrm{kg}(B)$ or betamethasone $1 \mathrm{mg} / \mathrm{kg}(C)$. The DA showed marked constriction $4 \mathrm{~h}$ after administration of indomethacin $(1 \mathrm{mg} / \mathrm{kg})$ and betamethasone $(1 \mathrm{mg} / \mathrm{kg})(D)$. Arrows indicate DA. later and immediately after cesarean section, maternal blood was drawn by cardiac puncture with a syringe containing $0.1 \mathrm{ml}(100$ $\mathrm{U})$ of heparin. Fetal blood was collected using heparin-coated funnels by a deep cut in the neck, and blood samples of fetuses of each litter were pooled and studied as one sample. Blood samples were kept at $4^{\circ} \mathrm{C}$ for 1 night before separation of plasma by centrifugation. Plasma samples were stored at $-20^{\circ} \mathrm{C}$ until measurement of indomethacin by gas-liquid chromatography (12). In some studies, sagittal cross sections of the heart and great vessels were photographed as reported previously (7).

The DA constriction results are expressed as means \pm SEM; indomethacin concentrations were expressed as means \pm SD. Two- and 3-way analyses of variance were used, and the statistical significance of differences between group means was determined by modified Student's $t$-test (13). The difference was considered to be significant if $p<0.05$.

\section{RESULTS}

In these five studies, including combined treatment with indomethacin and betamethasone, fetal death or absortion was not noted. However, fetuses with combined treatments with indomethacin and betamethasone showed decreased skin turgor and pallor. Sagittal cross-sections of the fetal heart showed markedly increased constriction of the fetal DA $4 \mathrm{~h}$ after administration of both indomethacin and betamethasone compared with indomethacin or betamethasone alone (Fig. 1).

The results of study 1 are shown in Figures 2 and 3. In nearterm rats, fetal DA constriction by indomethacin alone was moderate and DA/PA was $0.56 \pm 0.05$ (mean \pm SEM). Combined administration of betamethasone resulted in a marked increase in DA constriction, and the maximum effect was obtained with $1 \mathrm{mg} / \mathrm{kg}$ betamethasone. The DA/PA ratio was 0.17 \pm 0.03 with this dose. Betamethasone $(1 \mathrm{mg} / \mathrm{kg})$ alone caused only mild DA constriction with $\mathrm{DA} / \mathrm{PA}$ of $0.76 \pm 0.06$. In preterm rats, the fetal DA constricted more with combined administration of indomethacin and betamethasone than with indomethacin or betamethasone alone. The augmenting effect of betamethasone in combination with indomethacin was maximum at $1 \mathrm{mg} / \mathrm{kg}$, and the $\mathrm{DA} / \mathrm{PA}$ ratio was $0.33 \pm 0.03$. However, several differences were noticed between preterm and near-term rats. First, small doses of betamethasone $(0.01,0.1$ $\mathrm{mg} / \mathrm{kg}$ ) constricted the fetal DA more in preterm rats than in

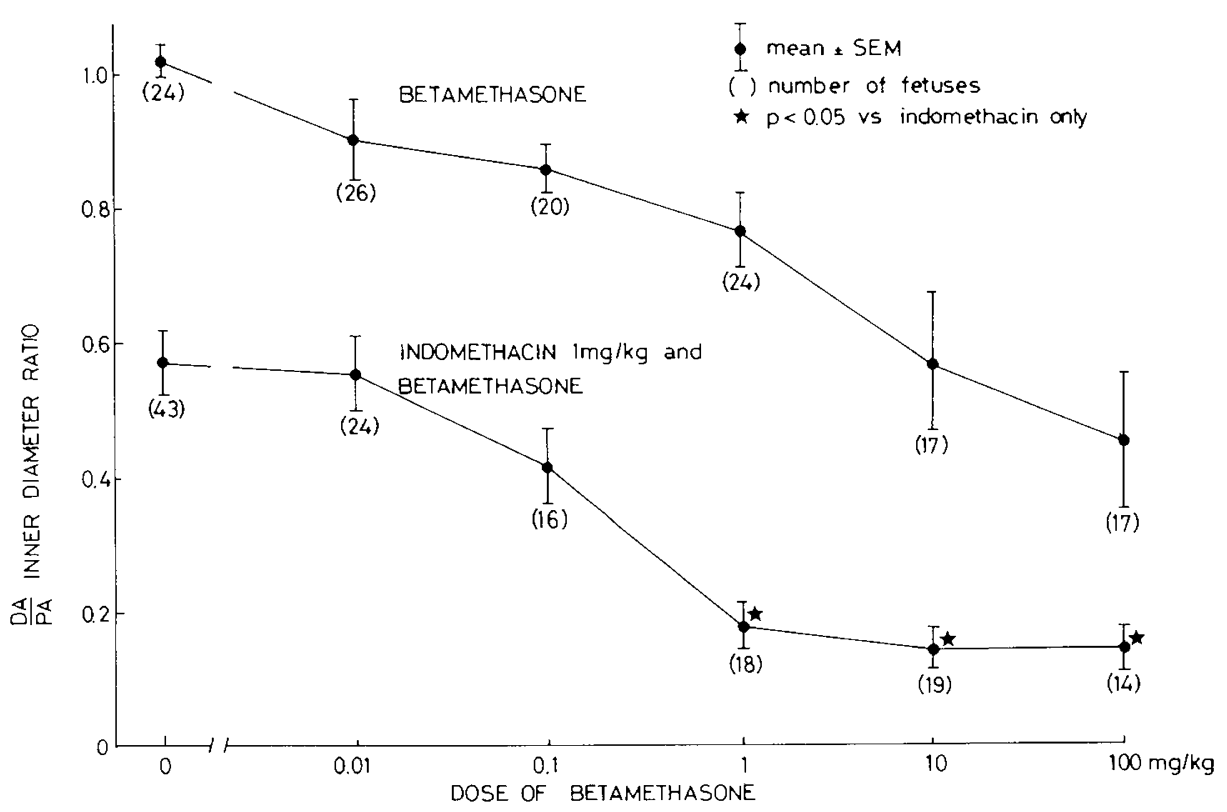

Fig. 2. Results of study 1 in near-term rats. Dose effects of betamethasone were studied $4 \mathrm{~h}$ after administration of either betamethasone alone or in combination with indomethacin $(1 \mathrm{mg} / \mathrm{kg})$. 
near-term rats $(p<0.05)$. Second, maximal constriction of the fetal DA was significantly smaller in preterm than in near-term rats.

The results of study 2 are shown in Figures 4 and 5. In both near-term and preterm rats, the fetal DA constricted significantly more at 1,4 , and $8 \mathrm{~h}$ after combined administration of indomethacin and betamethasone compared with indomethacin or betamethasone alone. The duration of fetal DA constriction was shorter in preterm than in near-term rats. At $8 \mathrm{~h}$ after administration of either indomethacin or betamethasone or both, DA constriction was significantly less than maximum in preterm rats, in contrast to the persistent maximum constriction at $8 \mathrm{~h}$ in near-term rats.

The results of study 3 are shown in Figures 6 and 7. The augmenting effects of separately administered betamethasone are noticed when it was administered 1,4 , or $8 \mathrm{~h}$ before the study in near-term rats, and $4 \mathrm{~h}$ before in preterm rats. However, administration of betamethasone $24 \mathrm{~h}$ previously did not augment DA constriction by indomethacin administered $4 \mathrm{~h}$ before death.

The results of study 4 are shown in Figures 8 and 9. In both near-term and preterm rats, fetal DA constriction by sulindac was augmented by combined administration of betamethasone.

The results of study 5 are given in Table 2. Fetal plasma indomethacin concentrations did not differ significantly between rats receiving indomethacin and betamethasone and those with indomethacin alone.

\section{DISCUSSION}

The present study demonstrates markedly augmented DA constriction by combined administration of indomethacin and betamethasone in fetal rats. Clyman et al. (14) reported that

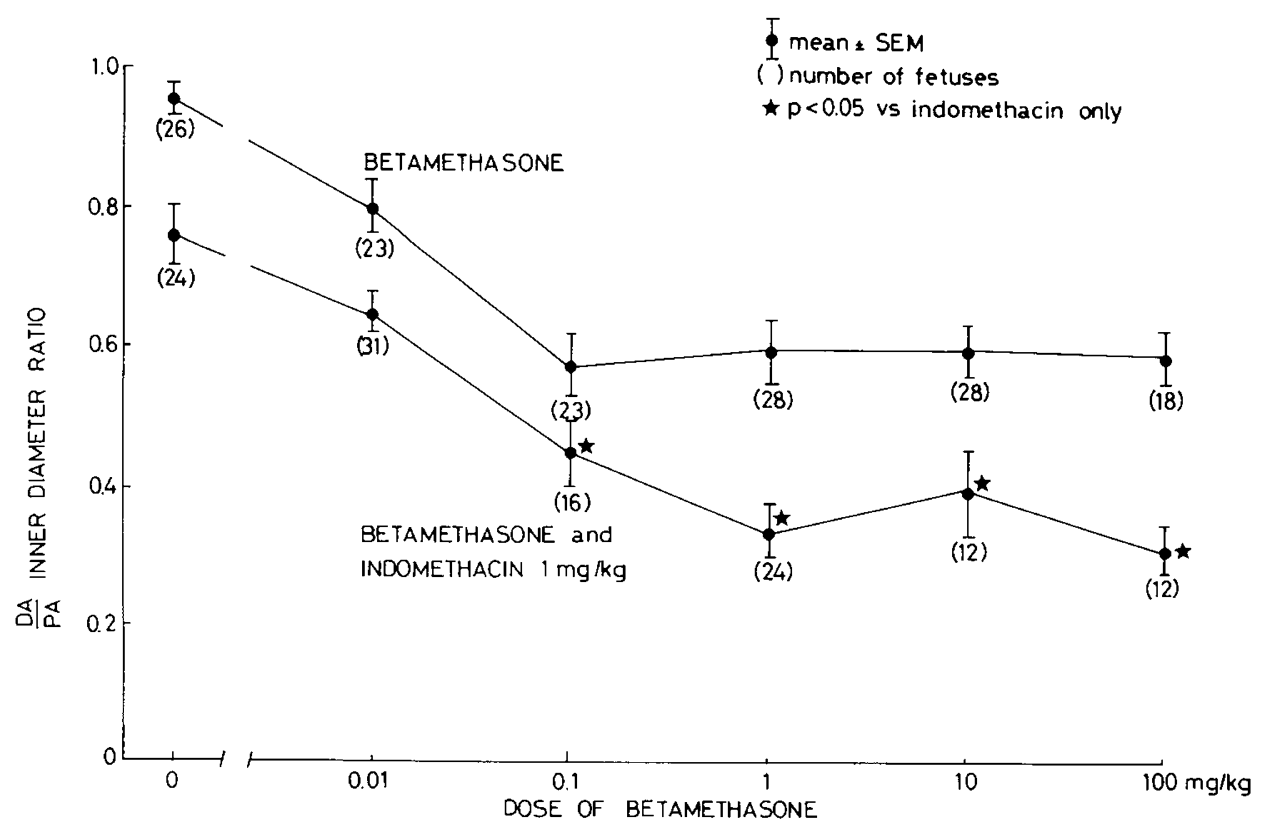

Fig. 3. Results of study 1 in preterm rats. Dose effects of betamethasone were studied $4 \mathrm{~h}$ after administration of either betamethasone alone or in combination with indomethacin $(1 \mathrm{mg} / \mathrm{kg})$.

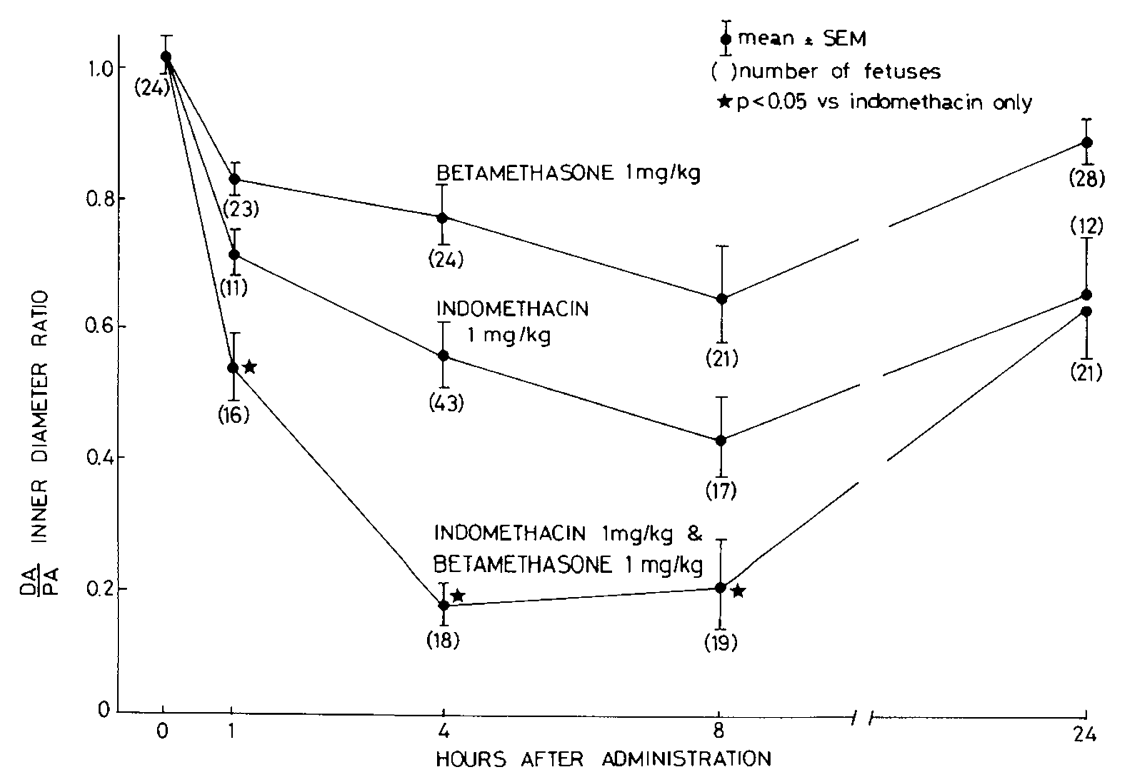

Fig. 4. Results of study 2 in near-term rats. Duration of fetal DA constriction was studied after administration of either betamethasone (1 mg/ $\mathrm{kg}$ ) alone, indomethacin $(1 \mathrm{mg} / \mathrm{kg})$ alone, or both betamethasone and indomethacin. 


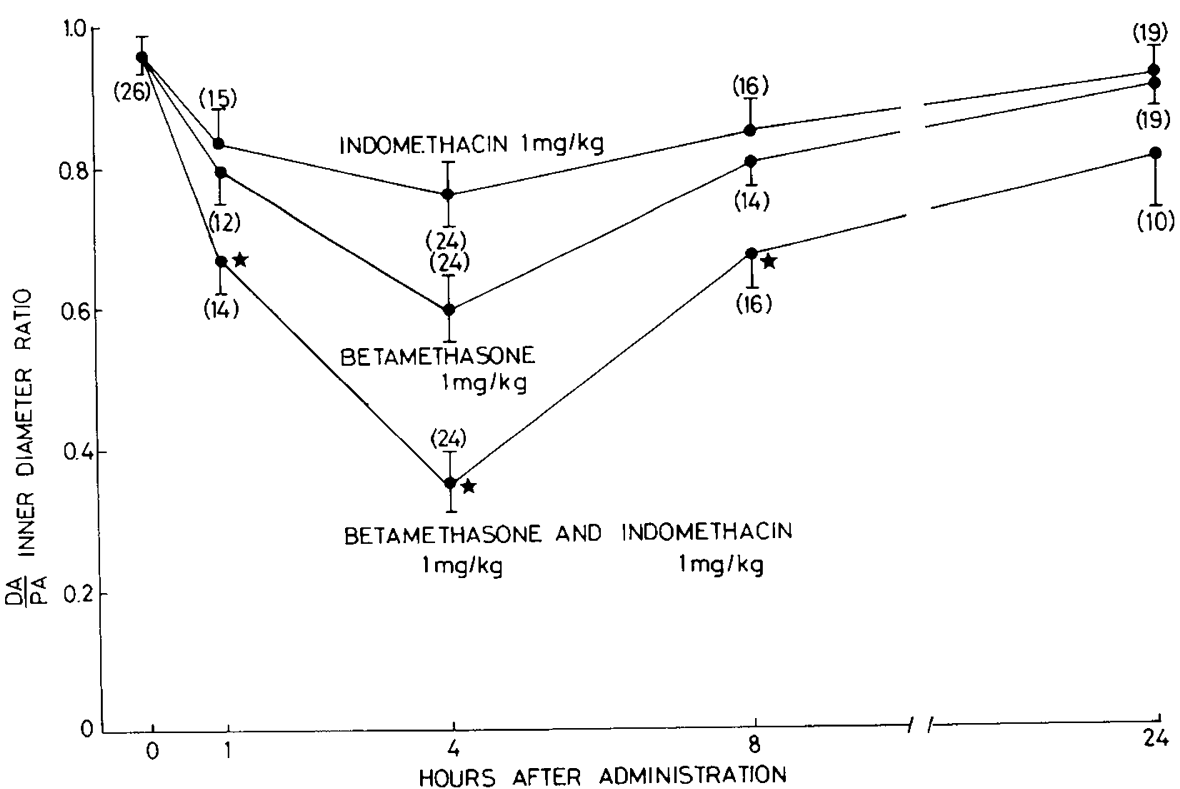

Fig. 5. Results of study 2 in preterm rats. Duration of fetal DA constriction was studied after administration of either betamethasone (1 mg/kg) alone, indomethacin $(1 \mathrm{mg} / \mathrm{kg})$ alone or both betamethasone and indomethacin.

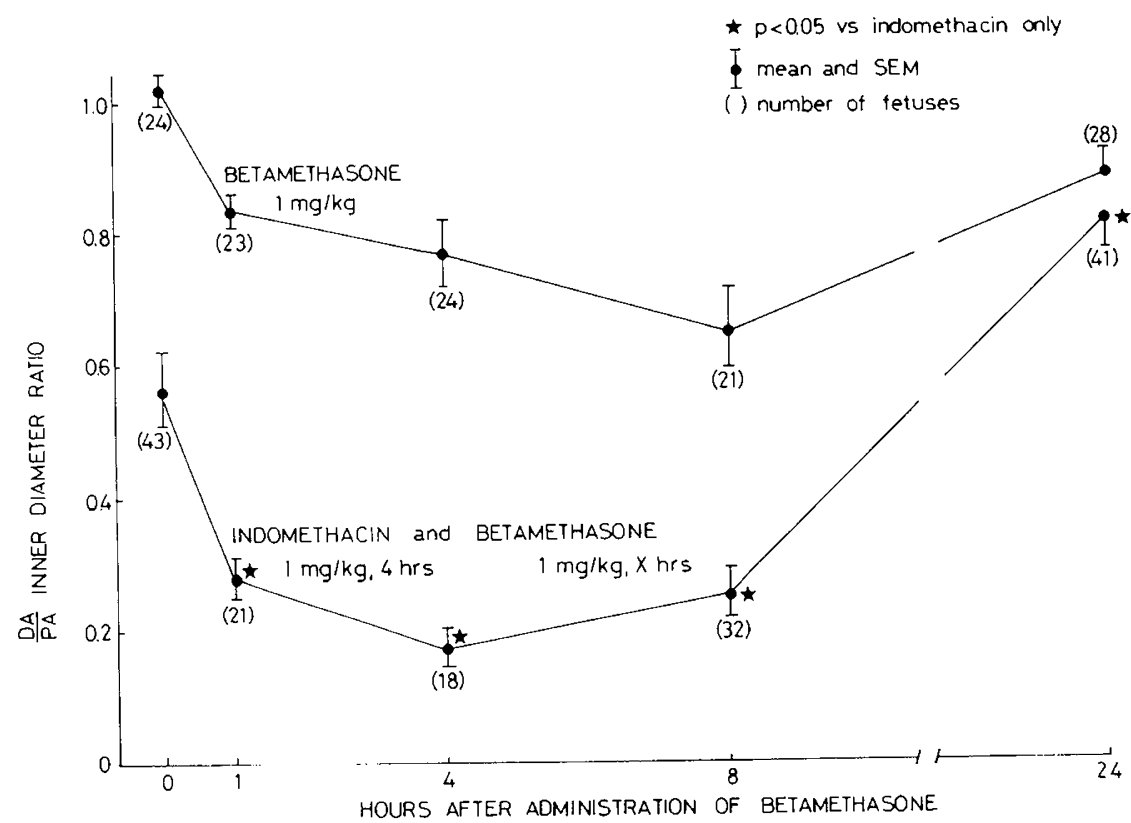

Fig. 6. Results of study 3 in near-term rats. Duration of constricting or augmenting effects of separately administered betamethasone $1,4,8$, or $24 \mathrm{~h}$ before rats were killed was studied alone or in combination with indomethacin $1 \mathrm{mg} / \mathrm{kg}$ administered $4 \mathrm{~h}$ before rats were killed. Asterisks show statistically significant values versus indomethacin alone.

pretreatment of the fetal lamb with infusion of hydrocortisone for $48 \mathrm{~h}$ caused a decrease in sensitivity of the fetal DA to prostaglandin E2. Their result is concordant with our findings, and explains synergistic effects of betamethasone and indomethacin in fetal DA constriction as follows.

Endogenous E-type prostaglandins are essential for physiologic patency and dilatation of the fetal ductus arteriosus (15). Indomethacin, sulindac, and other nonsteroidal antiinflammatory drugs inhibit cyclooxygenase and decrease endogenous levels of E-type prostaglandins, resulting in fetal DA constriction. As has been shown in fetal lambs given hydrocortisone (14), betamethasone is assumed to decrease DA sensitivity to E-type prostaglandins in fetal rats. This change in sensitivity acts to augment DA constriction due to a decrease in E-type prostaglandins. Thus, betamethasone and indomethacin have synergistic effects on the fetal ductus. The effect of betamethasone administered $24 \mathrm{~h}$ before, on the constriction by indomethacin administered separately $4 \mathrm{~h}$ before, is paradoxical. The underlying mechanisms of these phenomena remain to explored.

Clinical indications for combined administration of indomethacin and betamethasone in DA closure in preterm infants depend upon the individual clinical situation. As mentioned before, 1 $\mathrm{mg} / \mathrm{kg}$ of indomethacin administered to pregnant rats produced fetal plasma indomethacin concentrations comparable to plasma indomethacin concentrations in preterm infants treated with indomethacin (9). Plasma corticosteroid concentrations in nearterm fetuses and neonates are not greatly different (16). Plasma corticosteroids in infants with respiratory distress syndrome are 


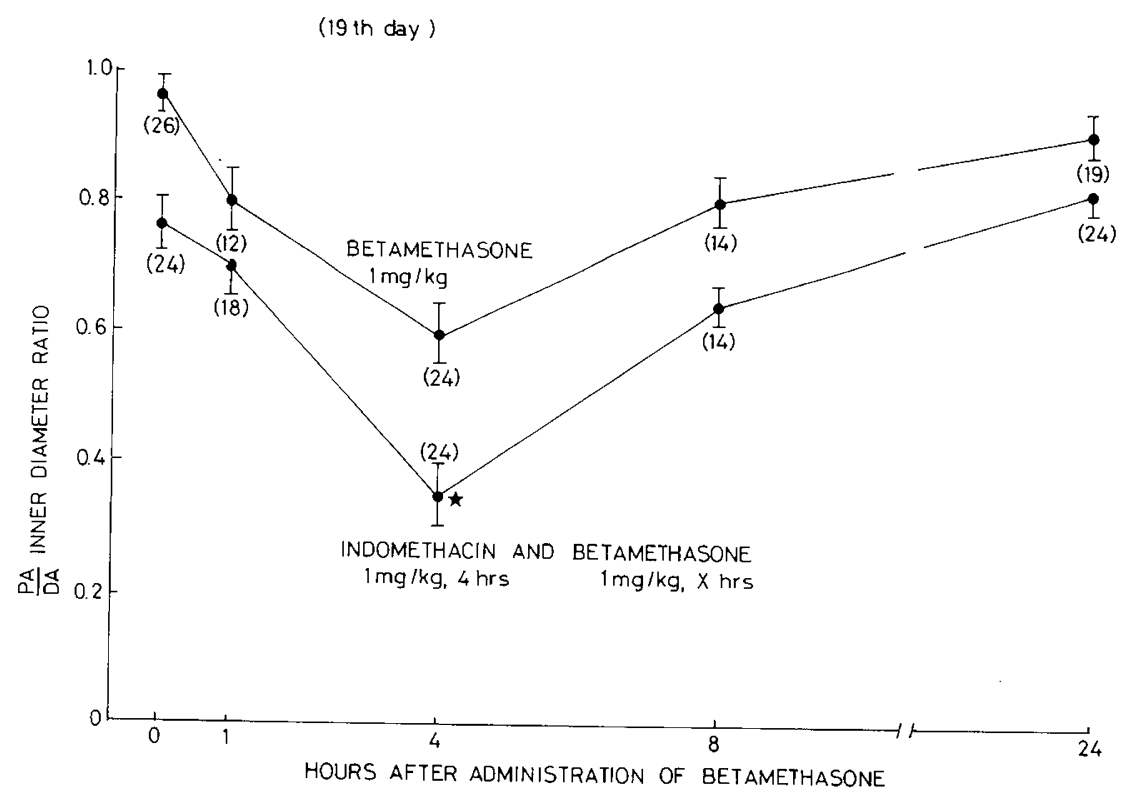

Fig. 7. Results of study 3 in preterm rats. Duration of constricting or augmenting effects of separately administered betamethasone $1,4,8$, or 24 $\mathrm{h}$ before rats were killed was studied alone or in combination with indomethacin $1 \mathrm{mg} / \mathrm{kg}$ administered $4 \mathrm{~h}$ before rats were killed.

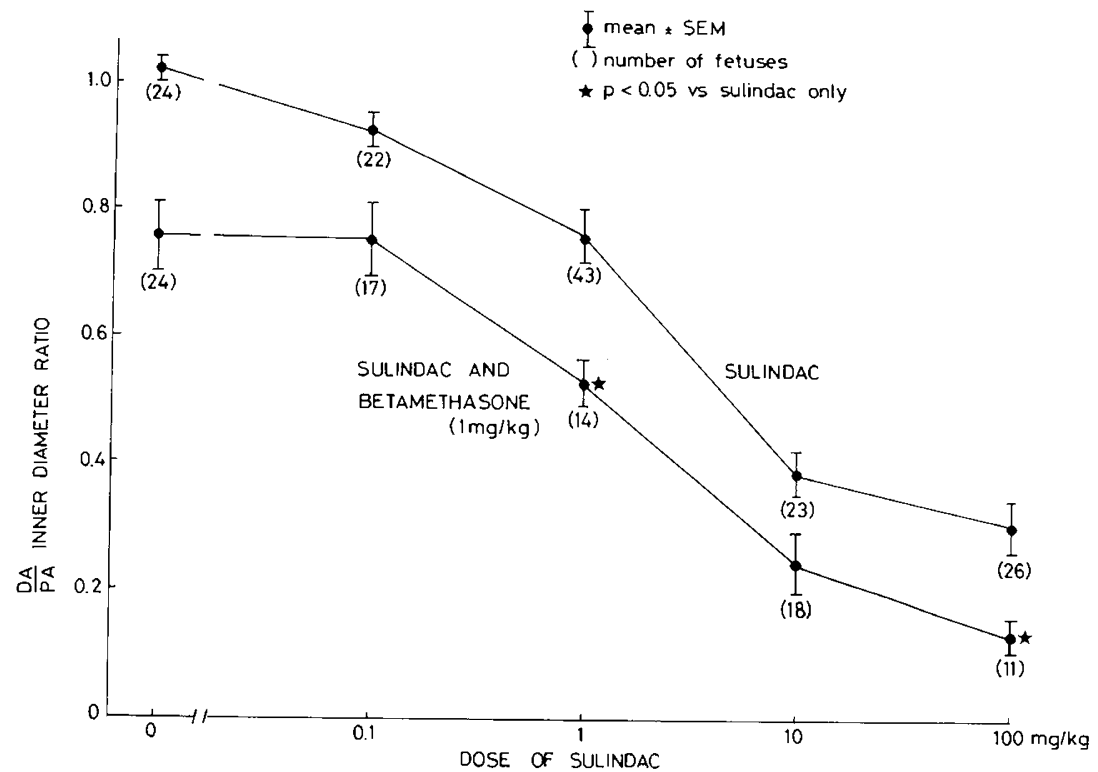

Fig. 8. Results of study 4 in near-term rats. Dose effects of sulindac alone and effects of combining betamethasone $1 \mathrm{mg} / \mathrm{kg}$ to sulindac were studied $4 \mathrm{~h}$ after administration.

Table 2. Plasma indomethacin (I) concentrations $(\mu \mathrm{g} / \mathrm{ml}) 4 \mathrm{~h}$ after administration of $1 \mathrm{mg} / \mathrm{kg}$ indomethacin alone or in combination with $1 \mathrm{mg} / \mathrm{kg}$ betamethasone $(B)$ in near-term rats (mean $\pm S E M)$

\begin{tabular}{lccccccc}
\hline \multicolumn{1}{c}{ Time after administration } & \multicolumn{2}{c}{$1 \mathrm{~h}$} & \multicolumn{2}{c}{$4 \mathrm{~h}$} & \multicolumn{2}{c}{$\mathrm{h}$} \\
\hline \multicolumn{1}{c}{ Dosage } & $\mathrm{I}(1)$ only & $\mathrm{I}(1)+\mathrm{B}(1)$ & $\mathrm{I}(1)$ only & $\mathrm{I}(1)+\mathrm{B}(1)$ & $\mathrm{I}(1)$ only & $\mathrm{I}(1)+\mathrm{B}(1)$ \\
\hline Maternal concentration & $3.10 \pm 0.48$ & $3.24 \pm 0.51$ & $2.75 \pm 0.35$ & $3.32 \pm 0.71$ & $2.81 \pm 0.47$ & $2.53 \pm 0.62$ \\
Fetal concentration & $0.52 \pm 0.06$ & $0.45 \pm 0.05$ & $0.65 \pm 0.05$ & $0.68 \pm 0.05$ & $0.51 \pm 0.06$ & $0.42 \pm 0.07$ \\
Fetal/maternal ratio & $0.17 \pm 0.04$ & $0.14 \pm 0.03$ & $0.24 \pm 0.05$ & $0.20 \pm 0.03$ & $0.18 \pm 0.04$ & $0.17 \pm 0.05$ \\
\hline
\end{tabular}

reported to be increased $(16,17)$. Because we did not measure concentrations of betamethasone in fetal plasma, we cannot compare the levels of endogenous glucocorticoids and fetal betamethasone. However, our data suggest that in preterm infants, $0.1 \mathrm{mg} / \mathrm{kg}$ of betamethasone can augment DA constriction by indomethacin, and a greater effect is expected with larger doses, such as 0.2 or $0.3 \mathrm{mg} / \mathrm{kg}$ of betamethasone.

In some preterm infants with a patent DA, renal dysfunction precludes administration of indomethacin. Sulindac is known to have little suppressive effect on renal function $(10,11)$. Therefore, sulindac can be used in infants with renal dysfunction. The combined used of betamethasone with sulindac is more effective in constriction of DA.

Another clinical concern is administration of nonsteroidal antiinflammatory drugs to pregnant women and side effects on the baby. Persistent pulmonary hypertension of the newborn is 


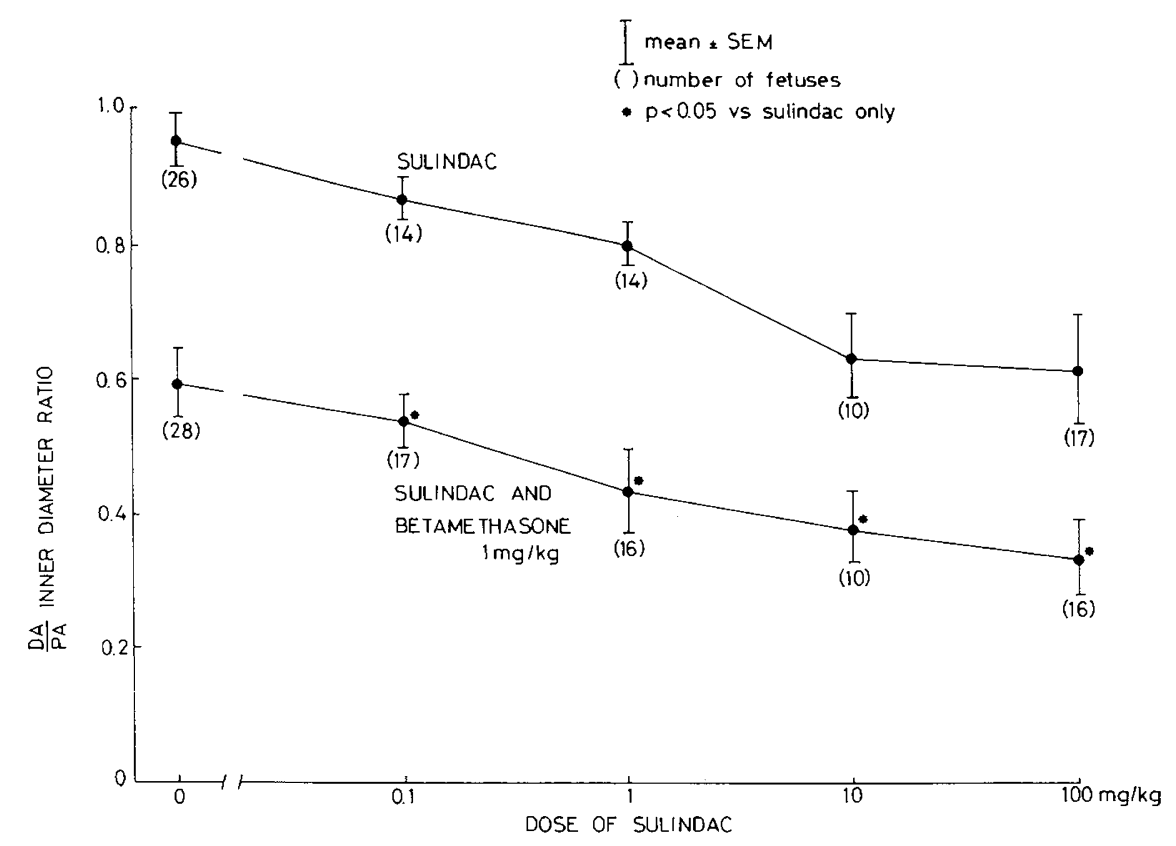

Fig. 9. Results of study 4 in preterm rats. Dose effects of sulindac alone and effects of combining betamethasone $1 \mathrm{mg} / \mathrm{kg}$ and sulindac were studied $4 \mathrm{~h}$ after administration.

a possible sequel of fetal DA constriction (15). Our recent study revealed that fetal DA constriction caused congestive heart failure followed by concentric hypertrophy of the right ventricle in fetal rats (18). From the results of this study, combined administration of nonsteroidal antiinflammatory drugs and glucocorticoid hormones to pregnant women increases fetal DA constriction and risk to the baby. Therefore, combined administration of these two drugs to pregnant women should be avoided.

Combined administration of betamethasone $(1 \mathrm{mg} / \mathrm{kg})$ with indomethacin or sulindac markedly constricts the fetal ductus arteriosus in both preterm and near-term rats. This augmenting effect of betamethasone was maximum with a dose of $1 \mathrm{mg} / \mathrm{kg}$ and persisted 1 to $8 \mathrm{~h}$ after administration.

Acknowledgment. The editorial help of L. M. Linde, Professor of Pediatric Cardiology, University of Southern California School of Medicine, is greatly appreciated.

\section{REFERENCES}

1. Friedman WF, Hirschklau MJ, Printz MP, Pitlick PT, Kirkpatrick SE 1976 Pharmacological closure of patent ductus arteriosus in the premature infant. N Engl J Med 295:526-529

2. Heymann MA, Rudolph AM, Silverman NH 1976 Closure of the ductus arteriosus in premature infants by inhibition of prostaglandin synthesis. $\mathrm{N}$ Engl J Med 295:530-534

3. Ivey HH, Kattwinkel J, Park TS, Krovetz LJ 1979 Failure of indomethacin to close persistent ductus arteriosus in infants weighing under 1000 grams. $\mathrm{Br}$ Heart J 41:304-307

4. Mellander M, Leheup B, Lindstrom DP, Palme C, Graham TP Jr, Stahlman MT, Cotton RB 1984 Recurrence of symptomatic patent ductus arteriosus in extremely premature infants, treated with indomethacin. $\mathbf{J}$ Pediatr 105:138-143
5. Momma K, Nishihara S, Ota Y 1981 Constriction of the fetal ductus arteriosus by glucocorticoid hormones. Pediatr Res 15:19-21

6. Momma K, Takao A 1987 In vivo constriction of the ductus arteriosus by nonsteroidal antiinflammatory drugs in near-term and preterm fetal rats. Pediatr Res 22:567-572

7. Momma K, Konishi T, Hagiwara H 1985 Characteristic morphology of the constricted fetal ductus arteriosus following maternal administration of indomethacin. Pediatr Res 19:453-500

8. Momma K, Takeuchi H 1983 Constriction of fetal ductus arteriosus by nonsteroidal antiinflammatory drugs. Prostaglandins 26:631-643

9. Yaffe SJ, Friedman WF, Rogers D, Lang P, Ragni M, Saccar C 1980 The disposition of indomethacin in preterm babies. J Pediatr 97:1001-1006

10. Bunning RD, Barth WF 1982 Sulindac. A potentially renal-sparing nonsteroidal antiinflammatory drug. JAMA 248:2864-2867

11. Ciabattoni G, Cinotti GA, Pierucci A, Simonetti BM, Manzi M, Pugliese F, Barsotti P, Pecci G, Taggi F, Patrono C 1984 Effects of sulindac and ibuprofen in patients with chronic glomerular disease. $\mathrm{N}$ Engl $\mathrm{J}$ Med 310:279-283

12. Helleberg A 1976 Determination of indomethacin in serum and urine by electro-capture gas-liquid chromatography. J Chromatogr 117:167-173

13. Wallenstein S, Zucker CL, Fleiss JL 1980 Some statistical methods useful in circulation research. Circ Res 47:1-9

14. Clyman RI, Mauray F, Roman C, Rudolph AM, Heymann MA 1981 Corticosteroids alter the sensitivity of the lamb ductus arteriosus to prostaglandin E2. J Pediatr 98:126-128

15. Levin DL 1980 Effects of inhibition of prostaglandin synthesis on fetal development, oxygenation, and the fetal circulation. In: Heymann MA (ed) Prostaglandins in the Perinatal Period. Grune \& Stratton, New York, pp 3544

16. Klein GP, Baden M, Giroud CJP 1973 Quantitative measurement and significance of five plasma corticoids during the perinatal period. J Clin Endocrinol Metab 36:944-950

17. Baden M, Bauer CR, Colle E, Klein G, Papageorgiou A, Stern L 1973 Plasma corticosteroids in infants with the respiratory distress syndrome. Pediatrics 52:782-787

18. Momma K, Takao A, Nishikawa T 1987 Right ventricular concentric hypertrophy and left ventricular dilatation by ductal constriction in fetal rats. Circulation 76:25 